УДК 66.078 .2

Кокошко Р.В., Кріль Б.А. к.т.н., Кріль О.В.

Національний університет „Львівська політехніка”

\title{
ЕКСПЕРИМЕНТАЛЬНЕ ДОСЛІДЖЕННЯ СТРУКТУРНИХ СХЕМ СИСТЕМ КЕРУВАННЯ МУЛЬТИКОМПРЕСОРНИМИ УСТАНОВКАМИ ДЛЯ ОДЕРЖАННЯ СТИСНЕНОГО ПОВІТРЯ
}

Стиснене повітря є універсальним енергоносієм для живлення різних виконавчих пристроїв в автоматизованих і роботизованих виробництвах. Проте системи для одержання стисненого повітря є одними з найбільших споживачів електричної енергії. Експериментальні дослідження перехідних прочесів роботи цих установок потрібні для створення більш ефективних алгоритмів роботи систем керування мультикомпресорними установками. Результати дослідження алгоритмів роботи систем керування мультикомпресорними установками з різними випереджуючими сигналами наводяться в иій статті. Структурна схема керування мультикомпресорною установкою складається $з$ головного вільнопрограмованого логічного контролера, на якому реалізовувались $i$ досліджувались алгоритми керування, та локальних контролерів окремих компресорних агрегатів. Суттєве покращення роботи системи керування мультикомпресорною установкою досягнене при введенні додаткового інформативного сигналу від швидкодіючого витратоміра для вимірювання витрати споживаного повітря.

Ключові слова: мультикомпресорна установка; компресорний агрегат; стиснене повітря; вільнопрограмований логічний контролер; частотний привід.

Вступ. Стиснене повітря - другий за поширенням після електричного струму енергоносій в сучасних промислових виробництвах. Його використовують для приведення в дію різного пресового обладнання для висікання або пресування заготовок та виробів 3 полімерних та металевих стрічок. Стиснене повітря рухає найрізноманітніші пневматичні виконавчі механізми пневмоциліндри, запірні і регулюючі клапани та засувки, вібратори. Перевагами таких механізмів $\epsilon$ висока швидкодія і великі зусилля при мінімальних розмірах і простоті конструкції. Перераховані пристрої придатні для роботи в вибухонебезпечних середовищах. Стиснене повітря використовують як реагент в технологічних процесах окислення, фракціонування, охолодження, фільтрування, продування, осушування, аерації.

Здебільшого, в кожному з згаданих вище технологічних виробництв застосовується мінімум як два повітряні компресори 3 середньою споживаною потужністю від 30 до 600 кВт [1,2], або більша їхня кількість. Як правило, на кожному успішно працюючому виробництві періодично проходить модернізація та нарощування виробничих потужностей і зростає споживання стисненого повітря. Це веде за собою збільшення кількості компресорних агрегатів. При застосуванні двох і більше компресорних агрегатів систему називають мультикомпресорною установкою [3].

В результаті модернізації підприємства компресорне обладнання буде складатися з агрегатів різної потужності, моделей різних років випуску і різних виробників. Це не $є$ якимось суттєвим недоліком, оскільки продуктивність таких створених в результаті нарощування виробництва мультикомпресорних установок має гнучко мінятись в залежності від споживання повітря i кількості задіяного технологічного обладнання. Для такої мультикомпресорної установки потрібно задіяти централізовану систему керування і критерієм іiї ефективності буде мінімізація енергозатрат та зменшення кількості вмикань та вимикань окремих компресорних агрегатів. Важливо виключити можливі моменти втрати керування мультикомпресорною установкою, що призведе до аварійної зупинки окремих технологічних ліній. Процеси втрати керування мультикомпресорною установкою розглянуто в роботі [3].

Витрати за весь час експлуатації компресорного агрегату для одержання стисненого повітря за даними [4] розподіляються наступним чином: витрати на електроенергію - понад $75 \%$, решту амортизація та поточне обслуговування. Це свідчить про те, що задача вдосконалення алгоритмів та схем керування мультикомпресорними установками є актуальною і ії навіть часткове вирішення зумовить значну економію електроенергії.

Для енергоефективної експлуатації компресорних агрегатів для одержання стисненого повітря застосовують різні методи керування агрегатами і організації їхньої спільної роботи. Один 3

() Кокошко Р.В., Кріль Б.А. к.т.н., Кріль О.В. 
найефективніших методів - це підтримання значення тиску стисненого повітря в системі 3 незначним перевищенням понад значення завдання [1,5]. Проте такий метод керування мультикомпресорною установкою потребує точного регулювання тиску при збуреннях з різними динамічними характеристиками та плавного перемикання компресорів для зменшення коливань значень тиску в системі.

На сьогоднішній день на тих підприємствах, які широко використовують стиснене повітря як енергоносій, $з$ компресорних агрегатів середньої потужності найчастіше поширені гвинтові компресора [1,2] зі змащенням або без нього, якщо стиснене повітря використовується при безпосередньому контакті з продуктом. Звичним $€$ те, що компресори часто оснащують частотними перетворювачами для плавного регулювання продуктивності. Застосування частотних перетворювачів в мультикомпресорних установках для одержання стисненого повітря забезпечує не тільки підвищення енергоефективності, а також дозволяє плавно регулювати продуктивність 3 мінімальними коливаннями значення тиску стисненого повітря на виході з системи.

Постановка проблеми. Ввід в роботу швидкодіючого преса після технологічної зупинки або коли в виробництві стиснене повітря використовують для охолодження, при вивантаженні продукту чи при підпорі буферної ємності з великим об'ємом, різко зростає миттєва витрата стисненого повітря. Такі процеси на великому виробництві можуть накладатися в часі або проходити окремо. Система керування мультикомпресорною установкою має швидко реагувати на зміну тиску та витрати повітря і утримати значення тиску стисненого повітря в заданих межах. Тому такі системи відносять до систем зі змінним навантаженням, де витрата стисненого повітря за лічені десятки секунд зростає або зменшується в кілька разів. Для прикладу, на рис.1 і рис.2 наведені історичні тренди зміни витрати на пивоварному виробництві. На рис.1 наведений приклад швидкого (більш ніж в два рази) зростання споживання повітря за 2 хв., а на рис. 2 - приклад зменшення споживання повітря (теж майже в два рази) за 5 хв.

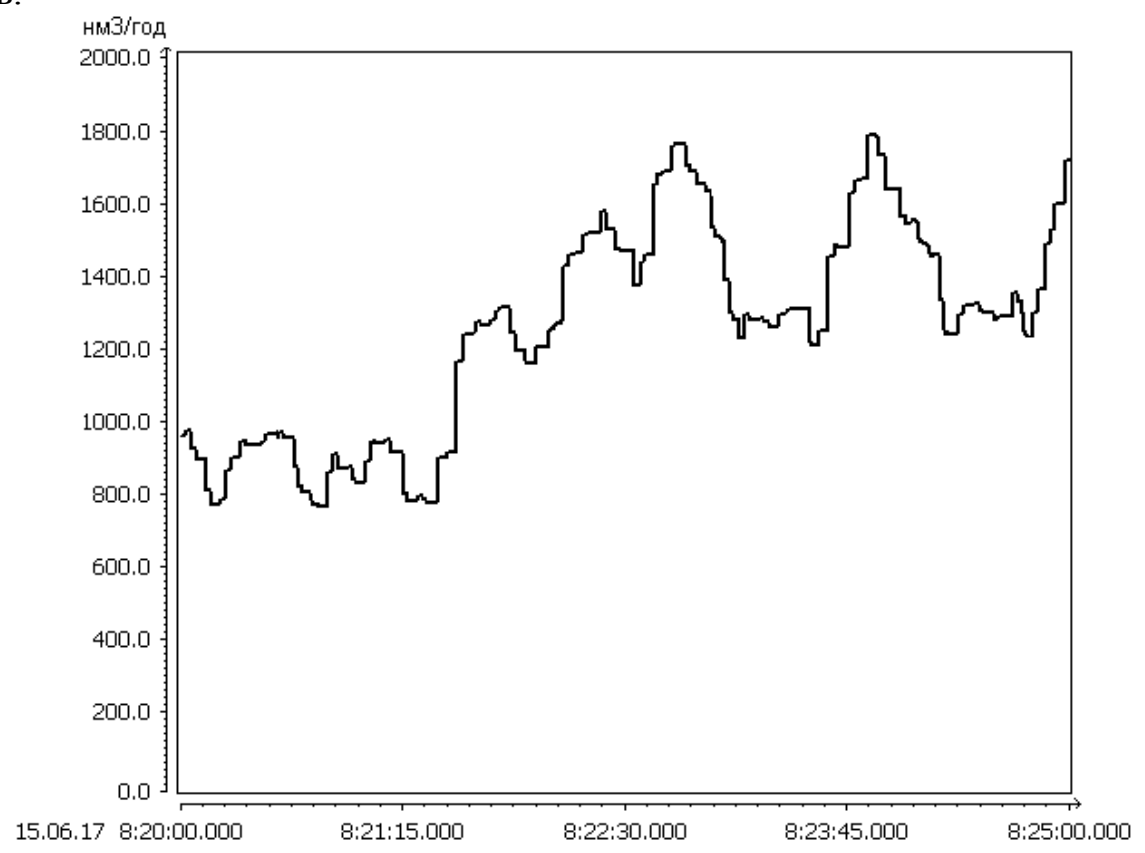

Рис.1. Історичний тренд збільшення споживання повітря на підприємстві ПрАТ «Карлсберг Україна» «Львівська пивоварня».

Якщо ставиться задача по забезпеченню енергоефективної роботи компресорних агрегатів для одержання стисненого повітря в мультикомпресорних установках має застосовуватися головний або центральний контролер, який вибирає компресорні агрегати потрібної продуктивності та вмикає або вимикає їх в потрібні моменти часу для забезпечення стабільного значення тиску стисненого повітря при різких змінах споживання $[1,5]$. Власне, вибір компресорних агрегатів, керування підготовкою їх до роботи в потрібному завантаженні, вибір моментів запуску чи зупинки, розрахунок завдання для компресорного агрегату, двигун якого живиться від частотного перетворювача входить в перелік складових алгоритму керування мультикомпресорною установкою для одержання стисненого повітря.

() Кокошко Р.В., Кріль Б.А. к.т.н., Кріль О.В. 


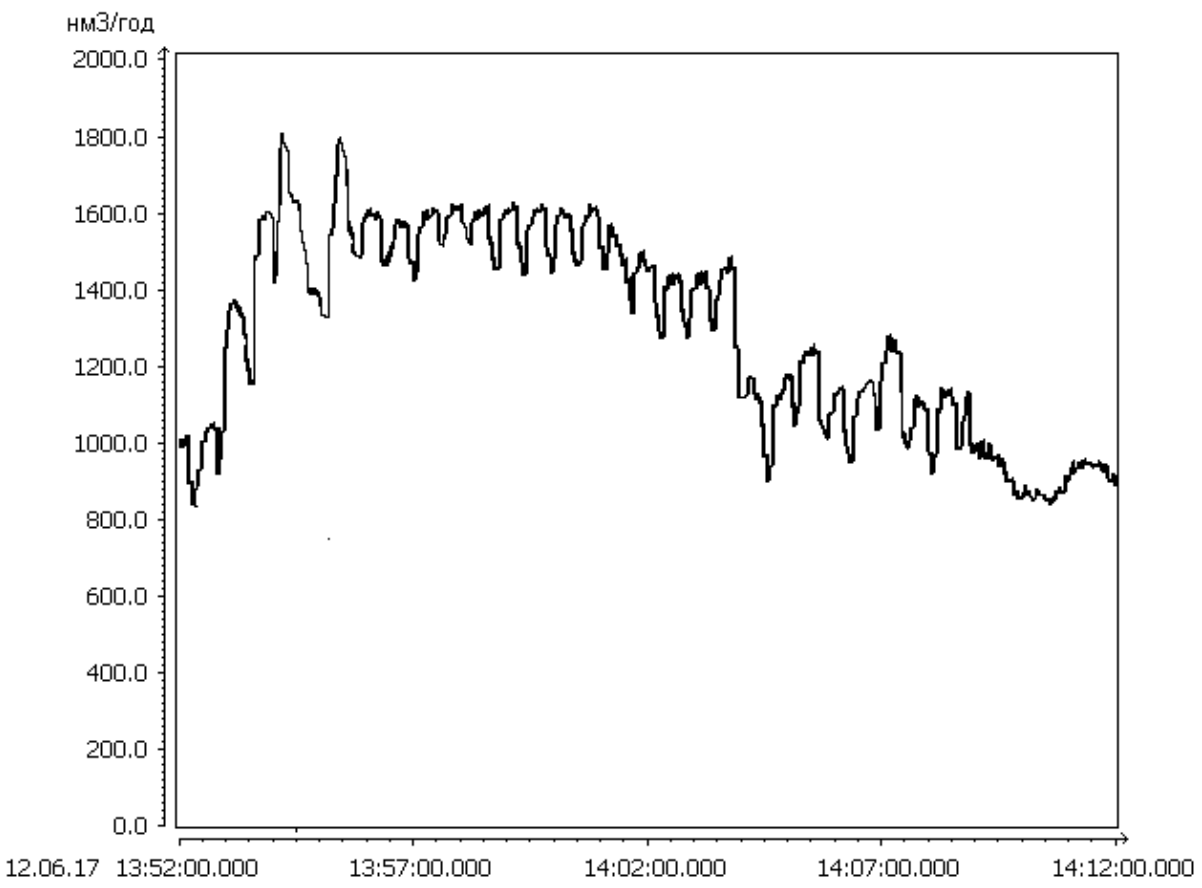

Рис.2. Історичний тренд зменшення споживання повітря на підприємстві ПрАТ «Карлсберг Україна» «Львівська пивоварня».

Найбільше підходять для застосування в якості головного чи центрального контролера вільнопрограмовані логічні контролери. Вони дозволяють підводити до них інформативні сигнали від давачів тиску, температури та витрати, гнучко враховувати особливості задіяних на підприємстві окремих компресорних агрегатів. Збір даних та передача їх на верхній рівень управління від таких контролерів не потребує залучення спеціалістів виробників компресорів або спеціального доступу до локальних контролерів окремих компресорних агрегатів.

Тому формування принципів та алгоритмів керування окремими компресорними агрегатами в мультикомпресорній установці є актуальним і очікувано забезпечить економію електроенергії та зменшить число пусків-зупинок окремих компресорних агрегатів.

Огляд структурних схем. Сучасні компресорні агрегати оснащуються індивідуальними системами керування, які керують ними в залежності від фіксованого завдання значення тиску чи завдання тиску в певних межах. Гвинтові компресори мають три режими роботи [1]: завантаження (режим при якому компресор працює і створює заданий тиск в системі), розвантаження (режим при якому компресор працює але не створює тиску в системі) та режим очікування( режим в якому компресор не працює, але очікує сигнал на запуск).

Споживання електроенергії в режимі розвантаження для компресорного агрегату складає 15-35\% [3] від споживаної при повній продуктивності, тому довготривала робота агрегату в режимі розвантаження знижує загальну енергоефективність мультикомпресорної установки.

Для керування мультикомпресорною установкою в складі декількох компресорних агрегатів 3 фіксованою швидкістю обертання приводів застосовують так звану каскадну схему керування. В такій схемі для кожної з індивідуальної системи керування виставляється свій певний діапазон значень тиску, при досягненні яких цей компресорний агрегат вмикається і працює. По досягненні верхнього значення тиску компресорний агрегат переходить в режим розвантаження $\mathrm{i}$, якщо тиск протягом заданого значення часу не зменшується, компресор переходить в режим очікування (див. рис. 3).

Така система керування можлива при застосуванні частотних перетворювачів для живлення двигунів компресорних агрегатів. В цих системах важливо правильно вибрати компресорний агрегат, привід якого буде живитися від частотного перетворювача, оскільки застосовувати частотні перетворювачі для живлення двигунів двох або більше компресорних агрегатів економічно недоцільно. Згідно із дослідженням [3] неправильний вибір компресора зі 


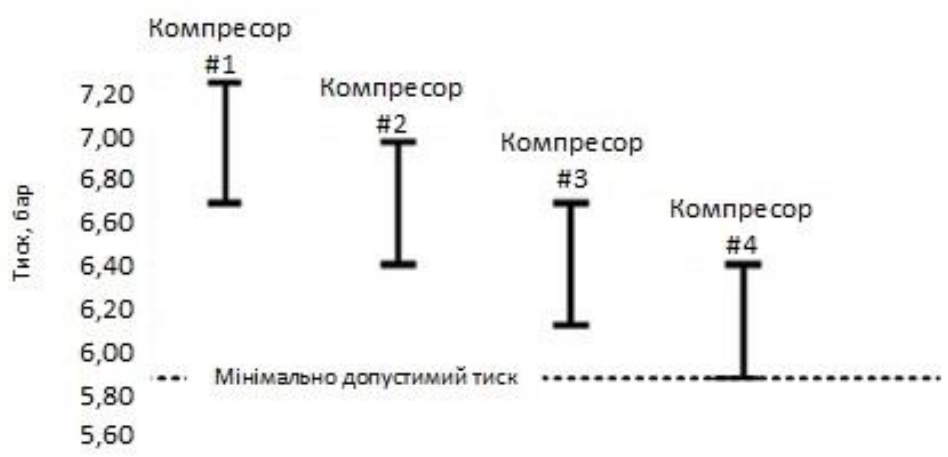

Рис.3. Каскадний алгоритм керування мультикомпресорною установкою з фіксованими швидкостями обертання приводів компресорних агрегатів.

змінним навантаженням призводить до одночасного ввімкнення двох і більше компресорів, при цьому компресорні агрегати 3 фіксованою швидкістю обертання постійно перемикаються 3 режиму завантаження в режим розвантаження, а компресор зі змінною швидкістю обертання працює в коливному режимі. Тому компресорний агрегат, який працює зі змінною швидкістю обертання приводу для зміни продуктивності, має забезпечити мінімально необхідну витрату стисненого повітря для підприємства. Це пояснюється тим, що виробники компресорів вказують мінімальну допустиму швидкість обертання двигуна, при якій допускається неперервна робота компресора. При постійній роботі такого компресорного агрегату 3 частотним перетворювачем на максимальній продуктивності споживання електроенергії буде більшим, ніж для аналогічного компресорного агрегату з фіксованою швидкістю обертання. Це зумовлюється коефіцієнтом корисної дії частотного перетворювача, додатковими втратами на двигуні за рахунок вихрових струмів, причому ці всі втрати часто недооцінюють. За даними [6] для компресорних агрегатів зі змінною швидкістю обертання приводу найбільш ефективна їхня робота досягається в межах до 80\% від максимальної продуктивності. При цьому згідно з [5] для компресорів 3 фіксованою швидкістю обертання найбільш ефективна робота в мультисистемних установках для одержання стисненого повітря забезпечується при роботі в режимі завантаження.

Найпростіша система керування компресорним агрегатом для режиму зі змінним навантаженням на основі вільнопрограмованого логічного контролера 3 застосуванням частотного перетворювача виглядає так, як це показано на рис. 4.

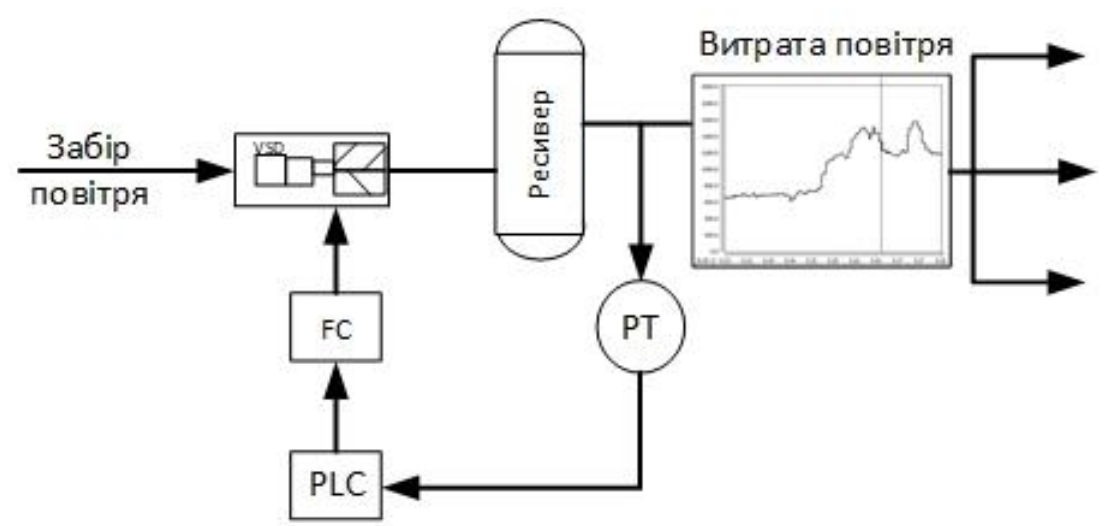

Рис.4. Структурна схема системи регулювання тиску зміною частоти обертання приводу компресорного агрегату, який працює при змінному навантаженні.

Така структурна схема придатна для окремого компресорного агрегату. Якщо ж паралельно 3 ним буде працювати ще один компресорний агрегат 3 фіксованою швидкістю обертання приводу, то в моменти ввімкнення та вимкнення або завантаження чи розвантаження буде виникати збурення, 3 яким PID - регулятор першого агрегату не справиться. Тобто, в моменти нанесення таких збурень доцільно впливати на PID - регулятор шляхом вимкнення I i $\mathrm{D}$ складових або зняття частини сигналу на виході регулятора, яку внесли ці складові.

(C) Кокошко Р.В., Кріль Б.А. к.т.н., Кріль О.В. 
Очевидно, що цю функцію має виконувати центральний чи головний контролер, який буде здійснювати загальне керування мультикомпресорною установкою.

Приклад значних коливань тиску при по каскадному ввімкненні компресорних агрегатів 3 фіксованою швидкістю обертання і роботі компресорного агрегату зі змінним навантаження на максимальній продуктивності показано на рис. 5.

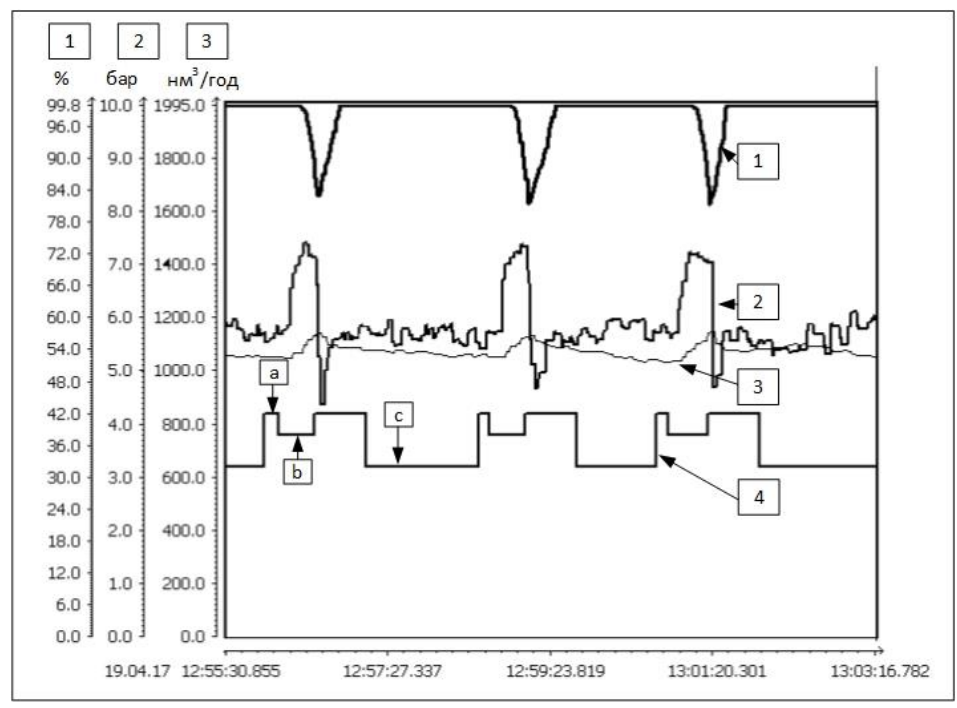

Рис.5. Історичний тренд роботи мультикомпресорної установки для одержання стисненого повітря при застосуванні PID-контролера в системі керування компресором, який працює в режимі зі змінним навантаженням. Де: 1 - завдання частотному перетворювачу 3 виходу PID-контролера, \% ( продуктивність даного компресора 1175 нм3/год); 2 - витрата повітря, приведена до нормальних умов, нм3/год (вимірюється методом змінного перепаду

тисків); 3 - тиск після фільтра, бар; 4 - діаграма роботи компресора 3 фіксованим навантаженням ( $\mathrm{a}$ - режим розвантаження, $\mathrm{b}$ - режим завантаження, $\mathrm{c}$ - режим очікування, компресор не працює).

Як видно з цього тренду, при роботі мультикомпресорної установки виникла втрата керування. В даному прикладі вона полягає в тому, що компресорний агрегат зі змінним навантаженням не встигає відпрацювати збурення, яке створюється при пуску компресора 3 фіксованим навантаженням. Очевидно, що в цій системі керування краще і ефективніше було б, якщо б компресор з постійною продуктивністю працював в базовому режимі завантаження, а компресорний агрегат зі змінним навантаженням відпрацьовував би всі ці відносно невеликі стрибки витрати. Для цього потрібно вдосконалювати алгоритм керування компресором зі змінним навантаженням. Він має мати специфічні особливості в моменти ввімкнення та вимкнення компресора, який працює з постійним навантаженням.

В роботі [7] пропонують змінювати інтегральну складову регулятора в залежності від величини параметру, який регулюється. Не зовсім ясно, як це зробити, оскільки такі регулятори - це регулятори зі змінною структурою та зі змінними параметрами. Для них є чіткі правила для зміни структури та зміни параметрів, наприклад, міняти коефіцієнт підсилення або інтегральну складову можна тільки при переході розузгодження через нульове значення, інакше це буде рівноцінне нанесенню стрибкоподібного збурення і введе систему керування в коливний режим роботи.

Автори роботи $[8,9]$ пропонують застосувати нечітку, так звану fuzzy, логіку для зміни параметрів PID регулятора в залежності від тиску в системі і швидкості його зміни. Але будьякий регулятор, який би мав реалізовувати нечітку логіку - це теж регулятор зі змінною структурою і змінними параметрами. Всі застереження, які описані в попередньому абзаці, справедливі і для цієї реалізації. Подібні алгоритми пропонуються для компресорних установок, що складаються з одного агрегату, хоча немає прикладів їх практичної реалізації і роботи в промислових умовах.

Очевидно, що для керування мультикомпресорною установкою для одержання стисненого повітря в умовах різких змін споживання алгоритми керування мають бути досить

() Кокошко Р.В., Кріль Б.А. к.т.н., Кріль О.В. 
складними і з чітко прописаними правилами зміни продуктивності агрегату зі змінною продуктивністю, порядком ввімкнення та вимкнення агрегатів 3 постійною продуктивністю, керування режимами завантаження та розвантаження. Однозначно, що з часом, по мірі введення нових додаткових випереджуючих сигналів (наприклад, ще один додатковий сигнал за витратою споживання найбільшого споживача), дослідники будуть їх вдосконалювати.

Вимоги до систем керування. При побудові систем керування мультикомпресорними установками для одержання стисненого повітря 3 застосуванням вільнопрограмованих контролерів в алгоритмі керування необхідно враховувати наступне:

1) алгоритм керування має мати змінну структуру та змінні параметри;

2) основний алгоритм має бути реалізований на головному вільнопрограмованому логічному контролері; локальні контролери окремих агрегатів мають бути сконфігуровані так, щоб не перешкоджати виконанню основного алгоритму;

3) потрібно експериментально визначити час пуску компресора 3 фіксованим навантаженням;

4) встановити час, при якому компресор може працювати в режимі розвантаження, та час переходу в режим завантаження;

5) вияснити обмеження по мінімально допустимій швидкості обертання приводу компресорного агрегату, при якій не порушуються режими охолодження та змащування;

6) доцільно розширити діапазон зміни частот живлення приводу компресора 3 частотним приводом до 55-60 Гц;

7) основним сигналом для роботи системи керування вважати значення тиску стисненого повітря на виході з ресивера після установки;

8) додатковим сигналом прийняти сигнал про значення витрати стисненого повітря на виході з установки.

Дослідження структурної схеми. Найчастіше для вимірювання витрати стисненого повітря застосовують витратомір на базі термоанемометричного методу вимірювання, наприклад, . Основним його недоліком $є$ недостатня швидкодія, що обмежує його застосування для одержання додаткового випереджуючого сигналу. Тому додатковий випереджуючий сигнал по зміні витрати повітря, найдоцільніше отримати при вимірюванні споживання стисненого повітря методом змінного перепаду тиску. Основною перевагою його є висока швидкодія, яку ще можна підвищити при застосуванні дифманометра 3 аналоговою схемою перетворення, оскільки для більшості інтелектуальних дифманометрів мінімальне значення сталої часу є на рівні 1 с. Застосований при введенні додаткового випереджуючого сигналу по витраті витратомір змінного перепаду розрахований на мінімально можливий перепад тиску для мінімізації втрат тиску на звужуючому пристрої. При цьому ми відійшли від обмежень, які диктуються правилами розрахунку стандартних звужуючих пристроїв [10], оскільки облік кількості спожитого повітря - технологічний, а більш важливе призначення цього витратоміра - формування випереджуючого сигналу по витраті для системи керування мультикомпресорною установкою.

3 врахуванням результатів попередніх досліджень була розроблена структурна схема системи керування мультикомпресорною установкою для одержання стисненого повітря, в якій вільнопрограмований логічний контролер виконує функцію головного, а локальні контролери систем керування окремих компресорних агрегатів сконфігуровані 3 максимальним адаптуванням в якості підпорядкованих головному контролеру. Ця структурна схема зображена на рис. 6.

Два компресорні агрегати працюють в режимі 3 постійною швидкістю обертання приводів, а двигун третього компресорного агрегату живиться від частотного перетворювача. В системі задіяні два інформаційні сигнали: перший - значення тиску в трубопроводі після ресивера, другий - значення витрати в трубопроводі після ресивера.

Розроблена система реалізована на ПрАТ «Карлсберг Україна» «Львівська пивоварня» $\mathrm{i}$ досліджувалась 3 двома алгоритмами роботи. В першому алгоритмі не застосовувався інформаційний сигнал про витрату споживаного повітря. Історичні тренди роботи системи керування відображали стрибки тиску повітря на виході мультикомпресорної установки і один 3 них вже був наведений вище на рис. 5.

В наступному вдосконаленому алгоритмі роботи системи керування мультикомпресорною установкою був задіяний сигнал про витрату споживаного повітря і 
приклад історичного тренду роботи мультикомпресорної установки за цим алгоритмом зображений на рис. 7.

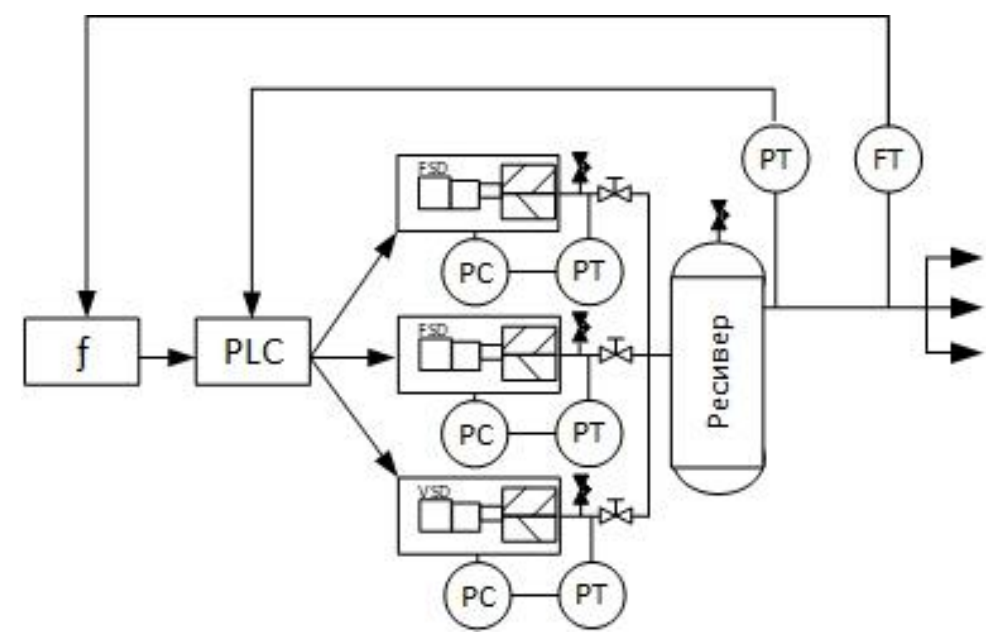

Рис.6. Структурна схема системи керування мультикомпресорною установкою для одержання стисненого повітря із застосуванням окремого головного контролера та додаткового зворотнього зв'язку по витраті. Де: FT - витратомір змінного перепаду тиску; РТ - давач тиску;

PLC - вільнопрограмований контролер; $f(\mathrm{x})$ - функція перетворення сигналу по витраті.

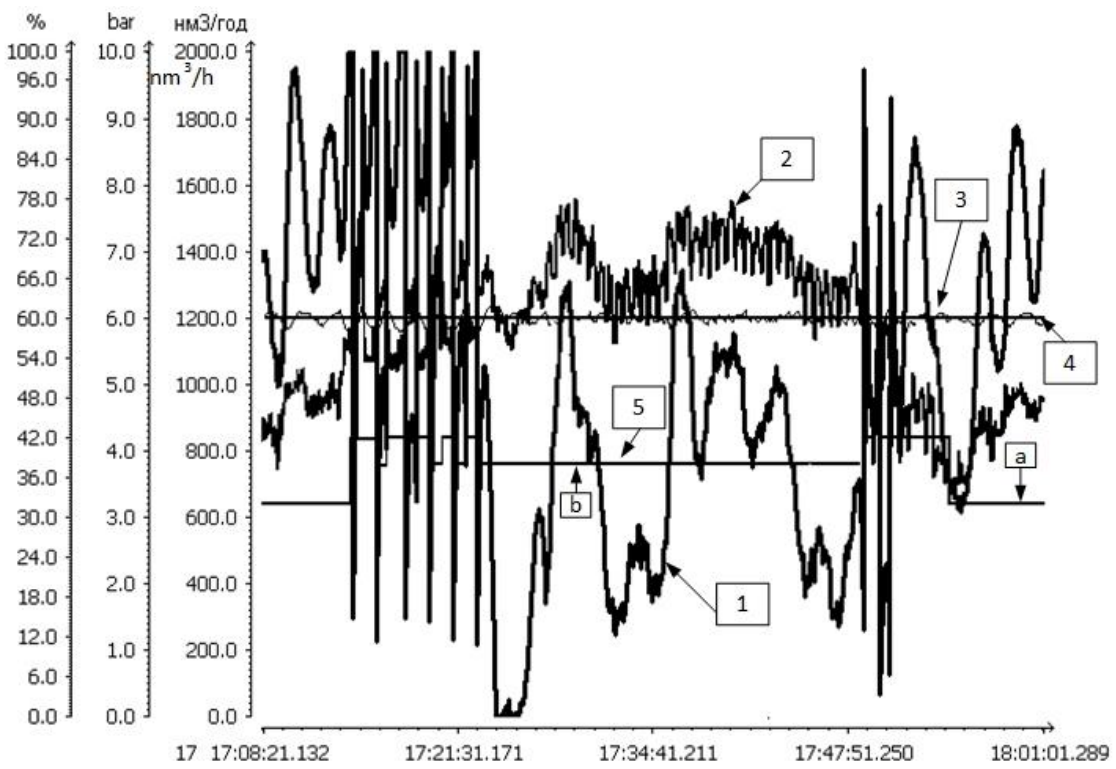

Рис.7. Історичний тренд роботи мультикомпресорної установки для одержання стисненого повітря при застосуванні в системі керування вільно програмованого логічного контролера і з введенням додаткового зворотнього зв'язку по витраті. Де: 1 - завдання частотному перетворювачу з виходу PID-контролера, \% ( продуктивність даного компресора 1175 нм3/год); 2 - витрата повітря, приведена до нормальних умов, нм3/год (вимірюється методом змінного перепаду тисків); 3 - тиск після ресивера, бар; 4 - завдання тиску після ресивера, бар; 5 - діаграма роботи компресора $з$ фіксованим навантаженням (a - режим розвантаження, $\mathrm{b}$ - режим завантаження).

Цей тренд підтверджує те, що при введенні додаткового зворотнього зв'язку по витраті повітря, загальному керуванні мультикомпресорною установкою від головного контролера забезпечується точніше підтримання значення тиску повітря на виході 3 установки при змінному споживанні. Другий алгоритм був впровадженим в діюче виробництво i застосовується на протязі 5 років. Підприємством підтверджені очікувані результати зменшення енергоспоживання для одержання стисненого повітря та зменшення кількості 
ввімкнень та вимкнень компресорних агрегатів, які працюють від приводів 3 постійною швидкістю обертання, зменшення кількості переводів компресорів 3 розвантаженого стану в завантажений і навпаки.

Сигнал по витраті споживаного повітря є більш інформативним i завадостійким, в порівнянні з сигналом за зміною тиску. Це можна пояснити наступним чином.

Обробка інформативних сигналів по тиску та по витраті з наступним прийняттям рішення про ввімкнення чи вимкнення компресорних агрегатів, переведення компресорів 3 розвантаженого стану в завантажений чи навпаки, формування завдання частотному перетворювачу приводу компресора зі змінним завантаженням, зміна структури та параметрів головного регулятора (вимкнення І-складової або скидання наінтегрованого значення вихідного сигналу головного регулятора) полягає в тому, що ці сигнали фільтрують, задають певні мінімальні та максимальні порогові значення, вимірюють зміну їх значень в часі. На сигнал по тиску накладаються пульсації тиску від окремих компресорів, які потрібно профільтрувати, сам ресивер вносить запізнення і зміну тиску з врахуванням потрібної зони нечутливості фіксують 3 значним запізненням. Для витратоміра споживаного повітря пульсації тиску від окремих компресорних агрегатів $\epsilon$ синфазним сигналом і дифманометр на звужуючому пристрої їх не сприймає. Сигнал від витратоміра фільтрується 3 мінімальною сталою часу, задається швидкість зміни витрати 3 невеликою зоною нечутливості. Тому рішення про керування окремими компресорними агрегатами можна сформувати швидше і коректніше.

Підтверджені експериментальні результати та висновки справедливі лише для класичної конфігурації мультикомпресорної установки, тобто, коли послідовно ввімкнені наступні складові: окремі компресорні агрегати; колектор для збору повітря від окремих компресорних агрегатів; ресивер; вихідний трубопровід, на якому встановлені витратомір та давач тиску; гребінка для роздачі повітря до споживачів.

Висновки. Сформовані основні принципи побудови алгоритмів систем керування мультикомпресорними установками середньої потужності. Досліджені режими споживання стисненого повітря пивоварним виробництвом. Досліджені тренди роботи системи керування мультикомпресорною установкою при реалізації двох розроблених алгоритмів. Експериментально підтверджено, що застосування додаткового випереджуючого сигналу від швидкодіючого витратоміра, який вимірює споживання стисненого повітря за методом змінного перепаду тиску, дозволяе створювати більш ефективні алгоритми керування мультикомпресорною установкою для одержання стисненого повітря.

Інформаційні джерела

1. US Department of Energy. Improving compressed system performance: a sourcebook for industry. -Washington : U.S. Department of EERE,2003. - $128 \mathrm{c}$

2. Brian S. Elliott. (2006) Compressed Air Operations Manual. - McGraw-Hill Education 2006,407 p.ISBN: 978-0-07-149184-6 MHID: 0-07-149184-8.

3. Neil Mehltretter(2012), "Proper Application of Variable Speed Compressors". World Energy Engineering Congress,2012,999-1015 p.

4. Radgen P. (2006). Mission 6.2: Energy Efficiency, Режим доступу: http://okolje.arso.gov.si/ippc/uploads/File/ Compressed_air_en.pdf :[13.04.2019]

5. Don van Ormer (2017) Режим доступу: https://www.airbestpractices.com/ system-assessments/compressor-controls/central-monitoring-and-control-multiple-air-compressors

6. Energy Efficiency of Compressed Air Systems/ Smaeil Mousavi,Sami Kara, Bernard Kornfeld// 21 st CIRP Conference on Life Cycle Engineering/ Procedia CIRP,2014. - 313-318p.

7. Chunyue PAN(2017) Air Compressor Pressure Control System Based On Gearshift Integral PID Controller. MATEC Web of Conferences 139, 00199 (2017) ICMITE 2017 DOI: 10.1051/matecconf/201713900199 https://www.matec-conferences.org/articles/matecconf/pdf/2017 153/matecconf_icmite2017_00199.pdf.

8. Chris Schmidt, Kelly Kissock (2005) Modeling and Simulation of Air Compressor Energy Use. ACEEE Summer Study on Energy Efficiency in Industry,July 19-22, 131 - 142p. https://aceee.org/files/proceedings/2005/data/index.htm.

9. J. Javadi Moghaddam, M. Madani (2010) A decoupled adaptive neuro-fuzzy sliding mode control system to control rotating stall and surge in axial compressors Expert Systems with Applications Volume 38, Issue 4, April 2011, Pages 4490-449 https://doi.org/10.1016/j.eswa.2010.09.122 . 
10. Pistun, Y.; Lesovoi, L.; Matiko, F.; Markovskyi, D \& Lesovoi, R. (2007) "RASKHODRU" CAD computer programme.Manual. Publishing House of "Institute of Energy Audit and Energy Carrier Accounting" CJSC, Lviv, Режим доступу :http://www.ieoe.com.ua [23.03.2020]

Кокошко Р.В., Криль Б.А. к.т.Н., Криль А.В.

Национальный университет "Львовская политехника"

\section{ЭКСПЕРИМЕНТАЛЬНОЕ ИССЛЕДОВАНИЕ СТРУКТУРНЫХ СХЕМ СИСТЕМ УПРАВЛЕНИЯ МУЛЬТИКОМПРЕССОРНЫЕ УСТАНОВКАМИ ДЛЯ ПОЛУЧЕНИЯ СЖАТОГО ВОЗДУХА}

Сжатый воздух является универсальным энергоносителем для питания различных исполнительных устройств в автоматизированных и роботизированных производствах. Однако системы для получения сжатого воздуха являются одними из крупнейших потребителей электроэнергии. Экспериментальные исследования переходных процессов работы этих установок нужны для создания более эффективных алгоритмов работы систем управления мультикомпрессорные установками. Результаты исследования алгоритмов работы систем управления мультикомпрессорные установками с различными опережающими сигналами приводятся в этой статье. Структурная схема управления мультикомпрессорные установкой состоит из главного свободнопрограммируемого логического контроллера, на котором реализовывались и исследовались алгоритмы управления, и локальных контроллеров отдельных компрессорных агрегатов. Существенное улучшение работы системы управления мультикомпрессорные установкой достигнуто при введении дополнительного информативного сигнала от быстродействующего расходомера для измерения расхода потребляемого воздуха.

Ключевые слова: мультикомпрессорные установка; компрессорный агрегат; сжатый воздух; свободнопрограммируемый логический контроллер; частотный привод.

Kokoshko R.V., ph.d. Krill B.A., Krill O.V.

Lviv Polytechnic National University

\section{EXPERIMENTAL STUDY OF THE MULTIPLE-COMPRESSOR CONTROL SYSTEMS STRUCTURAL DIAGRAMS FOR PRODUCING COMPRESSED AIR}

Compressed air is a versatile energy source for powering various actuators in automated and robotic industries. However, compressed air systems belong to the most energy-consuming equipment category. Experimental studies of the transients of these systems are needed to create more efficient algorithms of the multiple-compressor systems. In this article are given the results of the study of the multiple-compressors control systems algorithms with different leading signals. The block diagram of the multiple-compressors consists of a master programmable logic controller, which implements and investigates control algorithms, and local controllers of individual compressors. A significant improvement the multiple-compressors control system were achieved by introducing an additional informative signal from the air consumption high-speed flow meter.

Keywords: multiple-compressors; compressor; compressed air; programmable logic controller; frequency drive. 